\title{
The Work of Photography Reimagined: The Soviet Moment in
}

France, 1928-1934

Simon Dell

This essay examines the photographic practices of the French Communist Party during the 'Third Period', when the Communist International adopted its most intransigent policies. Through an analysis of the magazines Nos Regards and Regards sur le monde du travail, I show that the Communists adopted a montage technique which expanded the practice from juxtapositions on the page to juxtapositions orchestrated across the whole publication. Photographs were thus used to articulate the conflict between opposed economic and political systems through sustained comparisons of capitalist countries and the "fatherland of the International proletariat'. In the process, the magazines became collective works rather than miscellanies of individual articles, mounting a direct challenge to the practices of the bourgeois press. This challenge was also extended to the role of the press photographer, which the Communists proposed to supplant through the collaboration of worker photographers. Thus, the very work of photography was to be reimagined.

Keywords: montage, communism, photojournalism, worker photography, Nos Regards, Regards sur le monde du travail 
The issue of the trade journal Arts et Métiers Graphiques for April 1936 featured an essay on the composition of the weekly magazine. As the journal's title suggests, Arts et Métiers Graphiques dealt with the luxury end of the print trade and the essay on weeklies was submitted by a professional arbiter of taste, the art critic Florent Fels. He was concerned with the ways in which magazines should be differentiated from the daily production of newspapers, and he saw illustration as crucial in establishing this difference and securing the success of any weekly publication. For Fels, the task of editors was to draw from the vast and expanding archive of images a series of features which were timely but also more carefully considered than those submitted to newspapers under the pressure of daily deadlines. Effective organisation of the visual archive would aid editors in their work and Fels opens his essay with an image of this microcosm (figure 1). It shows an archive cabinet with photographic subjects catalogued and subdivided. Accordingly, 'Women' are 'nude', 'undressed', 'outdoors'. Yet such a single group of entries is evidently insufficient and anyone consulting this drawer is also directed towards 'Cinema' for 'Undressed girls and performers'. In this microcosm bodies and objects are available for recombination. Images of women, like images of cars and trains in neighbouring drawers, await selection. The world is already processed, and is reduced to a series of elements to be assembled into the magazine. Fels offers no particular comment on the larger implications of this organisation; he is not even one to marvel at the abundance of resources but he is prepared to imagine such a response. 'For the uninitiated, opening a cabinet drawer at random is bound to provoke some astonishment'. ${ }^{1}$ However, not everyone was content simply to display astonishment. Others took issue with this reduction of the world to resource and contested what they 
saw as the exploitative logic of the press. Their attempts to reimagine the work of photography are the subject of this essay.

The reimagining of photography was part of a larger project to counter the dominant political order, and in the interwar period it was part of the campaign waged by the Communist International. So it is appropriate to begin with the world of the bourgeois press and its casual misogyny, as the Communist press was explicitly set against these practices. The world Fels surveyed was one comprised of commodities, for the images in the filing cabinets are objects of exchange. Cars and trains, women and children are interchangeable and the cataloguing indicates as much; the process of filing is to make the gathered images readily accessible to the editors, who will then make the images accessible to the consumers of the bourgeois press. Thus, the picture archive differs from, say, a business archive or a medical one as the materials gathered are not significant as documents of an institutional history, nor do they assume their importance within a disciplinary practice. Rather, the materials in the picture archive are catalogued to be reproduced; however, the purpose of reproduction is not established in advance and instead depends on the contingencies of journalism. It is in this sense that the images are interchangeable, for they are not endowed with specific functions.

To counter the world as envisaged in this archive, the Communist press sought to shift attention from products to producers. Accordingly, in the first issue of the Communist photojournal Nos Regards, of May 1928, the introductory editorial was accompanied by photographs of those engaged in the labour process (figure. 2). The editorial was punningly titled 'Où vont nos regards'; it opens with a conceit: 
Imagine for a moment that through some catastrophe our world has been destroyed. Then, 2,000 years later and quite by chance, a scientist discovers a bundle of magazines and illustrated journals; these are the only traces of our civilisation. What image of the twentieth century would this present to our good researcher? ${ }^{2}$

The image, it turns out, closely resembles those photographic subjects Fels was to see catalogued; the magazines serve as 'a shop window', revealing merely a world of luxury peopled by stars and models. ${ }^{3}$ Against this, the editors of Nos Regards declare their intention to focus on 'the world of work', on all that 'the illustrated press persists in ignoring' even though it is 'infinitely more valuable and important' ${ }^{4}$ The contrast here is a pointed one; the 'shop window' displays commodities, whereas Nos Regards will be concerned with those who have laboured to produce such goods. Yet to assume its full force, this contrast required careful presentation. The shop window and the picture archive contained assembled products and it was important that the working body was not reduced to a further product. Labour power is a force, not a thing, and does not appear in shop windows but nevertheless producers could be defined - and catalogued by their products. This is what the first editorial of Nos Regards set out to reject for to make labour visible as a process leading to a product was, in important respects, to make it visible from the perspective of capital. Therefore the three photographs accompanying the editorial do not deal with final products. Two men stand with tools but have paused rather than being caught in action. A woman is washing, yet it is not clear what she is washing, or indeed where. And men are at work on a construction site but they are 
clearing as well as building. All these figures are workers, not artisans, and the photographs do not amount to a survey of skills and nor would they take a place in a picturesque review of the Parisian trades or petits métiers. ${ }^{5}$ Moreover, the figures are not posed and they do not directly acknowledge the camera (although two men at the construction site do seem to glance toward the photographer). And, finally, the pausing men and the washing woman direct their attention out of the frame so that the viewer is made aware of a world which is only partly accessible to view. There are a number of refusals here; the workers are not defined by product, practice or the conventions of portraiture. Instead, what is shown is what most commonly falls beneath the attention of journalists and archivists. There is no performance for the viewer, and no product for the consumer. Nevertheless, the editors of Nos Regards sustain their attention. They understand this as their task and as much is acknowledged in the pun of the editorial title. 'Où vont nos regards': 'Where we will look' and also, in this context, 'What we value'. These refusals were presented, quite forcefully, as part of an oppositional project.In what follows, I want to concentrate on the moment when this oppositional work was carried forward with the greatest intensity - that is, during the so-called 'Third Period' of revolutionary activity announced by Nikolai Bukharin in 1928. To do this I shall focus on Nos Regards, which was launched just as Bukharin's announcement was made; this publication was to be a weapon of the Parti communiste français (PCF). It was entitled Nos Regards in its first incarnation (1928-29), then Regards sur le monde du travail (1932-33) and then simply Regards (1933-39). I hope to show that the trajectory of this magazine in its first phases constitutes a significant chapter in the history of photography because it sheds light both on the operation of the bourgeois press and the 
ways in which this operation could be contested. During the relatively brief moment of the Third Period the magazine was used as a weapon in two ways: it presented a new form of montage, and it offered opportunities to a new type of photographer. In keeping with this, my argument has two parts, addressing in turn these different aspects of the work of photography. The first part concerns the uses of photography: how could photographs be made to articulate the conflict between opposing economic and political systems? The second part concerns the place of photography within the division of labour: to what extent should photographic practice itself be considered as work? These questions are of course related, as both concern conditions of alienation. The attempts of the PCF to address these two questions together defined the Soviet moment in France. ${ }^{6}$

\section{The Bolshevik Model}

To grasp the role and status of Nos Regards it is necessary to understand the tasks ascribed to the Communist press more broadly and this entails exploring what may be termed the Leninist narrative of Bolshevism. I describe it as a narrative because this history was given a particular form and teleology but the narrative is more than a myth in the pejorative sense of a fabulation. It did concrete work, especially so during the period after the revolutions of 1917. And the narrative should be termed 'Leninist' rather than Lenin's alone because it was co-opted by Stalin after Lenin's death. ${ }^{7}$

As set out in his early programme for the Social Democrats, drafted between 1895 and 1896, Lenin was committed to building a revolutionary party. The arguments he expounded for how to achieve this goal have what often seems a remorseless logic (albeit one that disguises certain tergiversations). In what follows I trace this logic only in its 
barest outline. Lenin's programme states that the paramount aim of the party is to assist the struggle of the Russian working class 'by developing the class-consciousness of the workers' and 'by promoting their organisation'. ${ }^{8}$ In his explanation of this programme, Lenin places the emphasis first on the development of class consciousness through action and second on the organisation which is necessary for successful actions. He is explicit in stating that the workers' actions must become a struggle for the ultimate goal of revolution; to achieve this goal the immediate task of the party was to convert the strike waves of the 1880 s and 1890 s into a greater force. ${ }^{9}$ However in Russia, as in other countries, there had emerged a split over how such a force was to be constituted and directed, a schism between those committed to social reform and those committed to revolution. For Lenin, revolution could only be achieved by rejecting what had come to be termed 'economism' and its limited demands for social reform; economic struggle had to be extended into political struggle.

This argument was developed at some length in 1902 in the pamphlet What is to be done? Here Lenin returned to the question of the development of a genuine classconsciousness, and asserted that this would only come about when 'the workers learn, from concrete, and above all from topical, political facts and events to observe every other social class in all manifestations of its intellectual, and political life' ${ }^{10}$ The working class must be led to proper consciousness and accordingly Lenin attributes - at least at this juncture - an important role to that distinctive figure of the turn of the century, the 'intellectual'. Such figures were required to perform vital roles in going among all classes as 'theoreticians, as propagandists, as agitators, and as organisers'. ${ }^{11}$ It follows that for Lenin this work takes a specific form; as the 'political struggle of Social- 
Democracy is far more extensive than the economic struggle of the workers against the employers', it is inevitable that the organisation of the revolutionary party is distinct from that of the trade union. ${ }^{12}$ So what indeed is to be done? The final part of Lenin's answer is given in the last chapter of his pamphlet. This is dedicated to a plan for an 'All-Russia Political Newspaper' and here Lenin set out the view that a 'newspaper is not only a collective propagandist and a collective agitator, it is also a collective organizer'. ${ }^{13}$ Thus the envisaged newspaper is presented as performing those vital roles identified earlier in Lenin's argument.

Yet if a revolutionary newspaper was to perform its roles effectively it was absolutely vital that all involved in its production submit to party discipline. This need for discipline was felt particularly acutely after the split between Bolshevik and Menshevik factions emerged with a new force at the party's Third Congress of April 1905. Whilst the revolution of 1905 would lead to closer collaboration of the two factions, when Lenin returned from exile to St Petersburg at the end of that year he once again took up the theme of party discipline. The occasion for this was his purging of the newspaper Novaya zhizn, which Maxim Gorky had funded and staffed with a broad coalition of writers. On this occasion Lenin wrote the brief essay 'Party organisation and party literature', which presents his case in the very order of the terms in its title. In this text the writers' subordination to party discipline is contrasted with unruly individualism in its various guises:

In contradistinction to bourgeois customs, to the profit-making, commercialised bourgeois press, to bourgeois literary careerism and individualism, "aristocratic 
anarchism" and drive for profit, the socialist proletariat must put forward the principle of party literature, must develop this principle and put it into practice as fully and completely as possible.

What is this principle of party literature? It is not simply that, for the socialist proletariat, literature cannot be a means of enriching individuals or groups: it cannot, in fact, be an individual undertaking, independent of the common cause of the proletariat. [...] Literature must become part of the common cause of the proletariat, "a cog and a screw" of one single great SocialDemocratic mechanism set in motion by the entire politically-conscious vanguard of the entire working class. ${ }^{14}$

This fundamental rejection of individual literary expression in favour of the disciplined party production also entailed the rejection of a widely accepted division of labour. Lenin declares

that literature must by all means and necessarily become an element of SocialDemocratic Party work, inseparably bound up with the other elements. [...] The organised socialist proletariat must keep an eye on all this work, supervise it in its entirety, and, from beginning to end, without any exception, infuse into it the lifestream of the living proletarian cause, thereby cutting the ground from under the old, semi-Oblomov, semi-shopkeeper Russian principle: the writer does the writing, the reader does the reading. ${ }^{15}$ 
So the Bolshevik model was to move beyond this principle, beyond old distinctions between intellectuals and workers. But this was not just a case of subordinating all party members to the same discipline. Here, Lenin's argument is a development of that in the conclusion of What is to be done?, for in refusing a distinction between writers and readers, Lenin is returning to a situation he has already sketched. His envisaged party newspaper was to function as propagandist and agitator and thereby become an organiser, and the contention in his 1905 essay is that those involved in the production of the newspaper would also be progressively transformed - effectively, readers would turn into writers. This principle of becoming is central to Lenin's view of party organisation; as Georg Lukács saw clearly, in Lenin's conception the party 'is simultaneously product and producer of itself ${ }^{3}{ }^{16}$

Of course, this conception of the party meant one thing at the close of 1905 , when discipline was required to maintain the revolutionary struggle in the face of defeat. It meant quite another in the transformed situation after 1917, when a different discipline was required to protect the advances made and to 'safeguard the socialist revolution'. ${ }^{17}$ Now the demand was for concerted action with 'the closest possible contact between the different sections of the revolutionary proletariat', and the Communist International (CI) was founded in March 1919 to secure this. ${ }^{18}$

There were twenty-one conditions for admission to the CI; in various ways these conditions were affirmations of the principle of 'democratic centralism' and were designed to exclude reformist elements. ${ }^{19}$ The final condition stipulated that those 'members of the party who reject in principle the conditions and theses put forward by the Communist International are to be expelled from the party'. ${ }^{20}$ Thus a mechanism was 
put in place to enable the subordination of the fledgling national Communist parties. With the ebbing of the revolutionary wave in Europe and the relative stabilisation of the early 1920s, it became evident to at least some elements of the CI that this subordination should be pursued with a particular rigour.

\section{From Bolshevisation to the Third Period}

In safeguarding the revolution, the CI was to fulfil two distinct - and potentially conflicting - functions: to prosecute worldwide proletarian revolution and to secure Soviet Russia. The paradoxical situation of the CI emerged clearly in 1921 when the Bolsheviks were able to claim victory in the civil war whilst also being confronted with the collapse of the revolution in Germany, the country in which Lenin had once placed his greatest hopes for success. If Soviet Russia was now more secure the world revolution was not and attempts to pursue the latter could in many situations jeopardise the former. There was, then, a continuing tension between a national and an international project. And because the CI emerged in the context of the revolutions in Russia, members of the Russian Communist Party had a decisive vote on the Executive Committee of the $\mathrm{CI}$ and thus the power struggles that would unfold within the Russian party would be reproduced within the International and its affiliate parties. ${ }^{21}$

After the failure of the revolution in Germany, the Third Congress of the CI reinforced the directive strength of the Executive Committee. There was a growing recognition that the Executive needed to adopt new tactics and the result was the "united front' policy whereby cooperation with socialist workers at the base was posited whilst collaboration with socialist leaders was rejected. How this policy was to be pursued 
depended on the views of the Russian Communist Party but this organisation was increasingly divided between a Left and a Right and these divisions only deepened as Lenin's health failed and his ability to control the party diminished.

Following an operation to remove an assassin's bullet in April 1922, Lenin suffered a stroke; the same month Josef Stalin became General Secretary of the party, which enabled him to curtail support for Leon Trotsky. During a partial recovery Lenin wrote a careful assessment of who amongst the Soviet leadership might succeed him but various figures were already manoeuvring when in March 1923 a further stroke left Lenin paralysed. Stalin had formed a 'majority' triumvirate with Grigorii Zinoviev and Lev Kamenev in order to marginalise Trotskyist 'opposition' and over the course of the year consolidated his power through various acts of patronage. The failure of the revolutionary action of the 'German October' in the autumn of that year entrenched the view that the defence of the Soviet Union should become the priority. With this failure and with further setbacks in Bulgaria and Poland the CI faced increasing criticism and, as its president, Zinoviev felt the need to reassert control over the young Communist parties. Henceforward a particular version of the Leninist narrative was to be propounded in a remorseless fashion.

New tactics were formally adopted at the Fifth Congress of the CI in 1924. The thirteenth thesis on tactics acknowledged that the tempo of the revolution could not be predicted and therefore the CI had to develop its capacity to manoeuvre. What this meant in practice is spelled out in the fourteenth thesis: 'In the present period the most important task of the $\mathrm{CI}$ is the bolshevization of its sections'. ${ }^{22}$ A genuine Bolshevik party was characterised as 'a centralized party, permitting no fractions, tendencies, or 
groups'. ${ }^{23}$ Such an organisation was held to be crucial to the success of the world revolution. 'Only to the extent that the decisive sections of the CI really become bolshevik parties will the Comintern become, not in words but in fact, a homogeneous bolshevik world party permeated with the ideas of Leninism' ${ }^{24}$ This international ambition was to have profound consequences for the ways in which the various Communist parties could operate within their respective national contexts. In the case of France Bolshevisation proceeded apace. The French delegation to the Fifth Congress successfully called for the exclusion of Boris Souveraine and he was soon followed, in December 1924, by Victor Delagarde, Alfred Rosmer, and Pierre Monatte; all four were allies of Trotsky. ${ }^{25}$

This purging took place in parallel to developments in the Soviet Union; also in December 1924, Stalin published an essay in which he applied Lenin's law of uneven development to Russia in such a way as to argue that 'the victory of socialism in one country' was 'quite possible and probable'. ${ }^{26}$ Stalin acknowledged that 'combined efforts' were still necessary 'for the final victory of socialism' and so international efforts must continue. ${ }^{27}$ Yet he also acknowledged that 'the first victorious country', the base for world revolution, required the support of the 'labouring masses of other countries' for otherwise it 'could not hold out'. ${ }^{28}$ This confirmed the priority given to the security of the Soviet Union and in turn this was to shift the priorities of the CI. However, the doctrine of pursuing socialism in one country led to a split in the triumvirate; Zinoviev and Kamenev moved into opposition to Stalin, who had formed a new faction with Nikolai Bukharin. This division came out into the open in October 1925, as preparations were made for the fourteenth party congress. Eventually, in 1926, Trotsky was to form a 
'United Opposition' with Zinoviev and Kamenev. Yet Stalin had by now consolidated his control of the party machine to the extent that he was able to oust his opponents. On 25 October 1926 the Central Committee of the Russian party deprived Trotsky of his seat on the Politbureau and announced that Zinoviev would no longer represent the party on the Executive of the CI, effectively deposing him. The final confrontation between Stalin and the United Opposition was drawn out over the summer and autumn of 1927. In October the three leaders were removed from the Central Committee and on 14 November Stalin and Bukharin organised a vote to expel the leaders from the party. This decision was ratified at the fifteenth party congress in December. ${ }^{29}$

Whilst Stalin entrenched himself, the Bolshevisation of the French party and in particular its anticolonial campaigns led to a series of denunciations and to the charge that the party was directed from Moscow and was a threat to French sovereignty. The most famous example of this charge came in a speech by Albert Sarraut, of April 1927, with its peroration: 'Communism, there is the enemy!' ${ }^{30}$ Nevertheless, such bellicose statements could be turned to some advantage, and were used by the PCF as evidence of the capitalist and imperialist threat to the Soviet Union. This was just one example of the rhetoric which lead to the 'war scare' of 1927 in the Soviet Union. Thus the Bolshevised parties came to be more aggressively positioned and this antagonism intensified over the course of 1928. As much was underlined when, on 5 May 1928, the CI adopted a new programme. This asserts:

Now two antagonistic systems are in conflict in what was once a single world economy — capitalism and socialism. The class struggle, which previously assumed 
forms determined by the absence of any State in which the proletariat held power, is now reproduced on an enormous and truly universal scale, for the working class of the whole world now has its own State, the only fatherland of the international proletariat. The existence of the Soviet Union, with its influence on the working and oppressed masses of the entire world, is in itself the clearest expression of the profound crisis of the world capitalist system and an unparalleled extension and heightening of the class struggle. ${ }^{31}$

In this analysis, the heightened struggle was an indication that the postwar world was entering a new phase. After the revolutionary period which reached its peak in 1920 and closed with defeats, there followed from 1923 a period of stabilisation as revolutionary activity moved from Europe to its colonies; this was now understood to be followed by a 'Third Period' of reconstruction in which the contradictions of capitalism were revealed ever more starkly.

This much was expounded at length at the Sixth Congress of the CI in the summer of 1928. In the account put forward by Bukharin, the intensification of class struggle marked clear divisions between the defenders of the Soviet Union and its enemies. The socialists, in blunting the vigilance of the working class, were to be denounced as 'social fascists'. ${ }^{32}$ The policy of fighting 'class against class' first adopted in February 1928 was now firmly endorsed..$^{33}$

Nos Regards 
The month in which the CI adopted its new programme also saw the publication of the first issue of the photojournal Nos Regards. The magazine was set up by Babette Gross and Lilly Becher; Gross was the partner of Willi Münzenberg and the brief for the new publication was to repeat the success of Münzenberg's German magazine ArbeiterIllustrierte Zeitung (A.I.Z.). ${ }^{34}$ Yet the French project was distinct from the autochthonous development of A.I.Z. because of the political context in which it emerged. A.I.Z. had first appeared in 1924 as a new incarnation of Sichel und Hammer, which in turn had emerged from Sowjet Russland im Bild. Münzenberg had begun publication of the latter in 1921 as part of his solidarity campaign Internationale Arbeiterhilfe, set up to bring famine relief to Soviet Russia. Münzenberg's magazines had links with the CI and indeed he had been invited to the First Congress of the CI to represent the Socialist Youth International. ${ }^{35}$ Yet the initial purpose of Münzenberg's German publications was to foster solidarity; his aim was to draw sympathisers towards the party and thus A.I.Z. addressed the diversity of German proletarian culture. ${ }^{36}$ Certainly, this project was to be refigured over the course of the 1920s, as divisions deepened between German Communists and Social Democrats. ${ }^{37}$ Nevertheless, Nos Regards had a different trajectory to its German precursors because from its first issue of May 1928 it had to respond to the conditions of the Third Period.

In its first incarnation, between May 1928 and October 1929, Nos Regards consisted of sixteen pages; the coverage settled quite quickly into the pattern of an opening page of topical photographs, Les faits $d u$ mois, followed by a series of features, with some confined to a single page and some allowed a double-page spread. Towards the back of the magazine, space was given over to fashion, sport, cartoons, and puzzles. 
The final page was a photographic miscellany. Whilst this arrangement of material was not unusual in the daily press of the 1920s, Nos Regards presented itself as a radical alternative. $^{38}$

The coverage in the first issue of Nos Regards is exemplary in pursuing the project set out in the opening editorial. The underside of the glamorous is to be exposed. Thus an essay by Diane Richmond on Casablanca does not revel in the exotic, even whilst it is illustrated with photographs provided by agencies that had the exotic as an important part of their stock-in-trade (figure 3). ${ }^{39}$ These images are not themselves transformed in Nos Regards; rather the viewer is called on to scrutinise them with a new discipline and a new empathy: 'The pretty young women seen here seem on the whole to have been chosen by the photographer for their charm and beauty. But, on closer inspection, one notices on every single face an expression of deep sadness, a sadness which for some of these poor women descends into despair'. ${ }^{40}$ In this account, the condition of objectification quickly becomes one of distress, and despair may be detected because the photograph is not simply of young women but of prostitutes from the 'reserved quarter' of the city. Whilst in some of the photographs the women present themselves to view, they are neither stars nor models but workers. The task of the coverage in Nos Regards, in the careful coordination of words and images, is to remove the women from a colonialist fantasy. The feature reworked the kinds of documentation used to support colonial exhibitions, the photographic juxtapositions which produced the familiar if unstable articulation of tradition and modernity, of the mission civilisatrice unfolding. ${ }^{41}$ In the postwar period, souvenir guides for such exhibitions frequently introduced coverage of individual colonies with aerial photographs as a means of 
showing the development of infrastructure and the advances made in civic planning. ${ }^{42}$ Here, Casablanca is treated in this fashion, with a photograph showing the expansion of the city towards the coast, and with recent building projects described in the accompanying text. However, it is also explained that the purpose of at least one of these projects has been the 'official installation' of brothels. ${ }^{43}$ And so, outlined against the aerial photograph of the city, there is an image of a semidressed prostitute: 'Afcha, one of the young "favourites" of the "white gentlemen". 44

The coverage in Nos Regards thus forces into proximity two aspects of patriarchy which are normally kept apart. One was a quite fraught discourse of oriental sensuality with a modern history stretching from Eugène Delacroix to André Gide; the other, of course, was that metropolitan authority which oversaw the development of 'la France d'outre-mer'. These aspects of patriarchy just brushed against each other in official publications where one might find both photographs of more decorously costumed 'natives' and images of new 'European' cities in North Africa. ${ }^{45}$ In such instances the women in traditional dress are picturesque rather than overtly eroticised and the tradition is present as a counterpoint to the modernising project of French colonialism. Usually, the combination of such images conveyed the rapid progress being made in a linear trajectory of progress from past to future. In Nos Regards, however, the projects and projections of patriarchy are entangled in a much more confused fashion. The introduction of French 'civilisation' to Casablanca has led to selective new building programmes but has also resulted in new forms of servitude and hypocrisy. In her commentary, Richmond draws attention to a feature of the photograph at the bottom of 
the page which may be taken to figure this particular form of uneven development: here the women of the 'reserved quarter' sit by an open channel for sewage.

The template established in the first issue of Nos Regards was soon elaborated. The staples and rubrics of the illustrated magazine were reconfigured. So, for example, the travelogue becomes the occasion for reflections on national rivalry and international solidarity; an early feature on Alsace has a photograph of Strasbourg cathedral but its caption draws out how the building has successively been claimed by France, then Germany, then France again. ${ }^{46}$

Yet the reimagining of photography in Nos Regards was not simply a matter of introducing a critical perspective and, where appropriate, a more empathetic register. The coverage of Casablanca had done this but, arguably, such coverage was not located within the revolutionary class struggle and was not sufficiently removed from the position of the French socialists. ${ }^{47}$ The signs of class struggle are everywhere to be seen for those prepared to acknowledge them and photographs could reveal them in many different ways. But it was not enough for Nos Regards to reproduce these signs and assemble its own archive. The class struggle had now to be grasped in its 'unparalleled extension' on a 'truly universal scale'; such was the programme of the CI for the Third Period. ${ }^{48}$ The task for the editors of Nos Regards was to find the means of figuring the true dimensions of the struggle. These means were offered by the very 'existence of the Soviet Union, with its influence on the working and oppressed masses of the entire world'. ${ }^{49}$ The oppressive structure of capital, with its advancing colonisation of everyday life, was to stand most clearly revealed when placed in contrast to those liberties already enjoyed in the Soviet Union. 
In principle, any aspect of everyday life could be used to mark this contrast. In the fourth issue of Nos Regards, of August 1928, images of the holiday season were reproduced to this end. Photographs in a double-page spread show various destinations of the privileged, such as Botofogo and Monte Carlo (figure 4). These destinations are spectacular or picturesque and are presented in conformity with the conventions of the postcard. In each case the camera has been placed at a distance from the motif so that details are subordinate to the whole. Each image is a unified 'view' and the captions describe them as such; the massed illumination of Monte Carlo at night 'dazzles' and Mount Fuji appears just as it does in so many 'Japanese prints' ${ }^{50}$ Yet the accompanying text emphasises that the locations which are eligible for treatment as postcards are precisely those from which the working class will remain excluded; these are destinations which workers will never reach, or reach only 'in their dreams' ${ }^{51}$ Composed as postcards, the photographs in the spread are also the converse of postcards; they do not record presence and experience but instead now register exclusion. They represent a world which workers may consume only as a series of representations on the printed page. Now, this is perverse and also seemingly rather pointless. However, on turning the page, the reader is presented with an alternative to such vicarious consumption and the full significance of the double-page spread begins to emerge.

The alternative is offered in a further feature on holidaymaking, where various forms of working-class leisure are represented (figure 5). The centre of the page is dedicated to a photograph showing the poor children who live in the Parisian zone and are confined there in both winter and summer, as the caption duly notes. However, there are counterpoints to this imprisonment; there is a photograph of children setting out to 
fish in Hyde Park in London and another of holidaying pupils from the Belgian school of Ovide Decroly. This juxtaposition of images suggests neglect on the part of the French state and as such may be taken as a particular development of the theme of exclusion. For the young zoniers are presented as the victims of 'a regime which wastes the best part of its money on budgets of death' for the army and navy. ${ }^{52}$ Moreover, below the photograph of the zoniers is an image of young Russian pioneers, camping in properly verdant countryside outside St Petersburg - a far cry from the bare earth of the abandoned Parisian fortifications. And a final photograph, in the bottom-right corner, mediates between these contrasting images of France and the Soviet Union. This is a photograph of children able to enjoy the French countryside because they are in the care of an orphanage supported by Münzenberg's Internationale Arbeiterhilfe. If the French state will not attend to the children of its less fortunate citizens, there is at least some indication that a Soviet world may be anticipated for France.

There is, then, a pointed contrast between the photographs of bourgeois resorts and the images of working-class recreation. The former views are exclusive (to reassert the language of class so often implicit in advertising copy). The latter are inclusive. Working-class leisure is represented as preeminently social: arms are linked, fishing nets shared, projects undertaken together. And whereas the bourgeois resorts are taken in from a distance, each photograph of youthful leisure is taken from a position of relative proximity, so that the viewer may share the space of recreation.

The quite basic opposition in the photographic treatment of these two themes is further underlined in the captions. These captions are used to emphasise the contrast between the fatherland of the proletariat and the capitalist states. As such they offer 
directives to the viewer, as Walter Benjamin was to note a few years later when reflecting on the status of illustrations in the press. ${ }^{53}$ In developing his discussion, Benjamin observed how the directives offered by the press 'soon become even more precise and commanding in films, where the way each single image is understood appears prescribed by the sequence of all the preceding images'. ${ }^{54}$ In Nos Regards something like this more commanding directive has already been issued. The sequence of images comprising a photo-essay bears comparison with the sequence of shots comprising a scene in a film; both may be used to establish a narrative (although the latter sequence will probably be more prescriptive). Yet whilst this comparison can be made, there is a significant divergence between any imagined film sequence and the orchestration of imagery in Nos Regards. In Nos Regards directives are created less through narrative sequencing than by what might be termed a principle of extended montage - one extended across the coverage offered by the magazine as a whole. This is the point of the sequence moving from Monte Carlo to the woods outside St Petersburg. Here a larger programme is articulated by the relationship between nominally distinct pieces of journalism. It is in establishing such relationships that Nos Regards is distinctive.

The distinction of Nos Regards was twofold: coverage was coordinated and photographic material was subordinated, submitted to its own form of party discipline. Here the contrast between Nos Regards and another new photojournal, $V u$, is instructive. ${ }^{55}$ Alongside reportage, a significant part of $V u$ 's coverage was driven by the novelty of its photographic material, from scenes distorted in the convex headlamps of cars to long exposures revealing the streaks of light created by such headlamps. ${ }^{56}$ This type of material was largely eschewed by the editors of Nos Regards, although the 
regular back-page miscellany, A travers le monde, did sometimes include photographic curiosities. $V u$ 's coverage was pointedly diverse. The press of the period tended to make a virtue of such diversity, and the variety could in turn be made a sign of a transparency; heterogeneity indicated an absence of programme and hence an objectivity. Such was the declared aim of $V u$, and the seemingly passive receptivity was signalled in the magazine's title. ${ }^{57}$ However, for those subscribing to Lenin's views, diversity of coverage could be taken as a sign of 'individualism, "aristocratic anarchism" and drive for profit', precisely because the diversity was oriented towards market position rather than to a political programme. ${ }^{58}$ In contrast, by establishing the principle of extended montage Nos Regards was able to articulate the programme of the CI in a new way. The work of photography was thus reimagined and reframed in the Leninist narrative as 'part of the common cause of the proletariat'. 59

As the common cause of the proletariat was the organising principle of Nos Regards, the heightening of the class struggle was to be shown in all its diverse aspects. Thus the fourth issue of the magazine extended the initial contrast established between the holidaying bourgeoisie, the deprived Parisian children, and the pioneers of the Soviet Union. The children of the zone had been described as the victims of a bellicose regime and the work of this regime was shown in the next spread. Here the class struggle was presented in its most acute form through photographs showing the carnage of the First World War, the results of recent colonial oppressions, and military manoeuvres in anticipation of further conflict. ${ }^{60}$ These images of the violence wrought by capitalism are then counterpointed by pacific activities in the fatherland of the proletariat as the final double-page spread in the issue is dedicated to an account of the Moscow 'Olympiades 
Spartakiades' ${ }^{61}$ This event is announced as a new chapter in the history of sport as it revives the true spirit of the games of antiquity. Vigorous, athletic bodies now replace those maimed in war. And once again, differences are underlined. The Moscow games are duly contrasted with the official, bourgeois Olympic games, which are readily presented as dressed in a 'false neutrality' ${ }^{62}$ Their spurious pacificism is thrown into relief by the preceding feature on war and rearmament. Moreover, the official games offer an instructive image of the inequalities of capitalism as each highly trained athlete is 'a type of monster', a product of an extreme social division of labour. ${ }^{63}$ Against this, those competing in Moscow are seen to have returned sport to its rightful status as the recreation of the working body. The gathering of these proletarian amateurs in Moscow was precisely a demonstration of common cause; the harmonious international assembly was presented as the alternative to the national rivalries played out in the official Olympics.

The different features in an issue of Nos Regards thus find their place in a larger whole. A corollary of this practice of extended montage was that 'individualism' of authorship was largely suppressed. This was not simply a case of anonymising the contributions of journalists and photographers (and indeed that was not done systematically). It is rather that the work of producing Nos Regards becomes collective, in that different contributions, on diverse topics, are submitted to the same perspective, that of the international proletariat engaged in the class struggle. This itself is a demonstration of political consciousness. Thus whilst Emile Dutilleul is listed in the capacity of director in the fourth issue, Nos Regards was not 'his' magazine; this was not a magazine to have a bourgeois proprietor. ${ }^{64}$ 
Once the coordinates for extended montage were established, they were consistently maintained. In the tenth issue of Nos Regards, for example, an anonymous author returned to the opposition between sport in the US and in the Soviet Union. ${ }^{65}$ In this double-page spread, sport in the most developed capitalist economy is shown as a mass spectacle orchestrated for commercial ends, whereas in the Soviet Union physical culture is a collective right (figure 6). In the image at the upper left of the first page, crowds are corralled around an individualised contest, in this case the boxing match between Jack Dempsey and Georges Carpentier. This is contrasted with the image at the bottom right of the second page, showing Russian citizens exercising in recreation grounds equipped with the latest facilities. That Nos Regards dedicated attention to sport was not in itself unusual; as the French press expanded and diversified at the end of the 1920s increasing amounts of space were given over to sports coverage and to other leisure activities. What is unusual is the way the coverage in Nos Regards was framed; different sports, for example, are presented not just within the immediate terms of the competitive event but also in relation to the antagonism of two systems. Here the US is the homeland of exploitation, at the opposite pole from the USSR. France is poised between these two, although effectively much closer to the former, and the images in the feature are made to reveal this larger situation.

The organisation of the photographic coverage in Nos Regards allowed images to show aspects of everyday life in the process either of being colonised or of being liberated. Yet giving this role to photography was only the first part of the project of reimagining; if the Communist task was to pursue the programme of liberation it would necessarily be thoroughgoing and would embrace more than just the content of 
photography and its signifying system. Lenin had anticipated as much in his essay on party literature. He argued that 'literature must by all means and necessarily become an element' of party work, but it was also necessary to ensure that this work went on outside the widely accepted division of labour; literary production, and by extension, photographic production, should also be liberated. ${ }^{66}$ The principle of collective production needed to be extended. How this was to be done was signalled in the coverage of sport and other leisure activities; for whilst under the capitalist system these activities had become further occasions for exploitation, in the Soviet Union they were reclaimed. Those exercising in the Soviet parks were exercising a self-determination, and one which needed to be progressively extended. In France this task was pursued when Nos Regards appeared in a second incarnation as Regards sur le monde du travail.

Regards sur le monde du travail Nos Regards ceased publication after a double issue for September and October 1929. If the magazine's trajectory was shaped by the conditions of the Third Period, it seems that these conditions also hastened its end. The policy of fighting 'class against class' had swiftly reduced the presence of the PCF in the Chamber of Deputies and was also eroding its membership. And in the summer of 1929 the party suffered increasingly under the repressive measures of André Tardieu, a minister for the interior who was happy to take up the cudgels on behalf of enemies of Communism such as Albert Sarraut. These were not propitious circumstances for the maintenance of a relatively large circulation magazine. ${ }^{67}$ 
Yet the tactics of the Third Period also served to complete the work of Bolshevisation, and to implant the PCF as a proletarian party and secure its reproduction as such. ${ }^{68}$ Once this was achieved in the summer of 1931 the general secretary of the party, Maurice Thorez, was able to announce a new and more flexible approach which was intended to be less sectarian and more engaged with the masses. ${ }^{69}$ In this context, the project of Nos Regards was resumed and a new magazine appeared at the beginning of 1932. ${ }^{70}$ The first issue of Regards sur le monde du travail did not contain an editorial but a note to the reader was included in the second issue, of February 1932, and here, once again, the coverage is pitched against the bourgeois press. The editors declare themselves committed to presenting 'the most striking social and political events, topical satire, and the stark contrasts created by the global crisis, with its scenes of unprecedented poverty'. ${ }^{71}$ Thus there is a clear continuity with the earlier magazine but there is also - quite unsurprisingly - a direct acknowledgement of the new conditions produced by the Wall Street Crash and the onset of a global economic depression. And whilst the mission of the new magazine is to report on the capitalist economies stricken by the crisis, it will also show the quite different situation which obtains in 'that other world of work, that of the Soviet Union, where workers are masters of their own destiny' ${ }^{72}$ Accordingly, in the February issue one finds a contrast between squalid Parisian tenements and new luxury flats in Argenteuil, and these images of inequality are juxtaposed with the world of the Soviet Union, in this case presented through Soviet citizens enjoying winter sports in the Caucasus as part of their allocation of three weeks of annual holiday. ${ }^{73}$ 
Regards sur le monde du travail was launched at a specific conjunction, just as Nos Regards had been. The new spirit of engagement which Thorez was seeking to promote was embraced in the first note to the reader:

'REGARDS' can and must become a magazine on which its readers collaborate. It will be what its readers want it to be because it editors will always be open to comments, criticisms and suggestions.

The more collaborators we have, the more writers and photographers, the greater the range of topics we will be able to treat and the more attractive our magazine will become, precisely because it will be the work of our readers. ${ }^{74}$

Yet the language here is not merely an echo of Thorez. A call for new collaborations was also made at this point by the newly founded Association des Ecrivains et Artistes révolutionnaires. The association's manifesto was published across two issues of L'Humanité in March 1932; this text opens with a discussion of conflict closely modelled on the account presented in the 1928 programme of the CI:

The class struggle assumes a universal scale as two systems confront each other: a rotting imperialism and a youthful socialism. [...] For the first time since the Paris Commune, the proletariat have their own State, one which transcends frontiers. The workers have their own country and, with the second Five Year Plan, a new dawn is breaking over that country, the dawn of a classless society. A new civilisation begins. ${ }^{75}$ 
Of course, the revolutionary struggle is ongoing, and the task of the association is to contribute to the new culture arising and to prepare its victory. 'The imperialist epoch reveals the decay and collapse of bourgeois culture. [...] Here as well two worlds are starkly opposed. It falls to the proletariat to revive a universal culture' ${ }^{76}$ This work of regeneration on the cultural front necessarily involves the rejection of bourgeois methods. ${ }^{77}$ And so the authors of the manifesto cite Lenin: 'literature cannot be a means of enriching individuals or groups: it cannot, in fact, be an individual undertaking, independent of the common cause of the proletariat'. ${ }^{78}$ Yet the citation of 1932 is not a mere repetition of 1905 for the circumstances are no longer those of the revolutionary struggle as conceived at that date. Now the workers have their own country and there is a model for a new literature provided by the Soviet worker correspondents, the so-called rabcors; these correspondents will be 'the wellspring' which will 'constantly renew the ranks of proletarian writers' ${ }^{79}$ And the aim of the association is to swell these ranks in order ' $[\mathrm{t}] \mathrm{o}$ develop an art of the masses embracing the newest expressive means: workers' theatre [...] photomontage, cinema, radio, etc' ${ }^{80}$ The rabcors had already set to work on this programme and their contributions were already to be seen in the pages of L'Humanité ${ }^{81}$ Regards sur le monde du travail was to provide them with another forum. Accordingly, in the March issue of the magazine there was a call for the collaboration of worker photographers. The original project of Nos Regards had been to present the world of work and now it was acknowledged that workers themselves were in the best position to make this presentation. Their perspective will make the definitive break 'with the bourgeois style with which we are unfortunately still conditioned' ${ }^{82}$ The 
break is necessary, for the bourgeois style is not just corrupt, it is corrupting. Returning once more to the terrain surveyed by Fels, the readers of Regards are invited to

judge the pose of a film actress or a "star", as paraded through the masscirculation magazines. Some will say it is a harmless pleasure to flick through these pages. The bourgeois class knows this is a means of distracting the workers, whilst also doing "good business".

The readers of 'REGARDS' have extricated themselves from this swamp. They have not abandoned their class. ${ }^{83}$

Accompanying the call for collaboration are two photographs; these images are themselves the results of collaboration, as the captions make clear that they have been contributed by amateur worker photographers. One photograph shows a man digging and the other shows five men resting at the end of the day (figure 7). The images are of work and respite; this seems clear enough. Yet what is less clear is what status one should ascribe to the images in this context. How is one to understand the production and consumption of these images? Should they be described as the results of work or the fruit of leisure? Of course, the distinction between work and leisure is itself the product of a class society. The task, ultimately, is to overcome this distinction. This is what has been begun in the Soviet Union, where a new civilisation arises. As much had already been made clear in Nos Regards, with its presentation of the stark contrast between the commercial distractions of bourgeois societies and the properly recreative activities undertaken in the Soviet Union. So with the call for the collaboration of workers as 
photographers there is an extension of collective production. Workers are now to move from passive consumption to active production, as the work of photography is again reimagined. The rabcors have set the example. Thus one may glimpse here something other than 'the old, semi-Oblomov, semi-shopkeeper Russian principle: the writer does the writing, the reader does the reading, ${ }^{84}$

Yet it is difficult in the French context to do more than glimpse the possibility of moving from reading to writing. This was in part because the policies of the PCF were overtaken by events. Whilst Thorez had announced new policies in 1931 he continued with the stance of fighting 'class against class' and here he was not alone; this stance was maintained by the CI even after Hitler took power in January $1933 .{ }^{85}$ However, the threat of fascism was belatedly recognised and various attempts were made, nationally and internationally, to effect a rapprochement between Socialists and Communists. It is hardly surprising that the initial attempts were faltering, given the aggressive character of the Third Period.

In France, it was the national rather than the international context which led to effective joint action of Communists and Socialists. On 6 February 1934, various groups demonstrated against the new government of Edouard Daladier; the night ended in riots and the following day Daladier resigned. His government became the first since 1870 to be brought down by violence. In response, a general strike was called for 12 February; the Socialists decided to hold demonstrations on this day and then the PCF made the same decision. 12 February came to mark a moment of reconciliation between the parties and would lead, albeit by a circuitous route, to a pact of unity, which was sealed in July 
1934. Thorez would not waste too much time in calling for the pact to be extended to a broad Popular Front. ${ }^{86}$

As the policy of fighting 'class against class' was reconsidered and then abandoned, Regards sur le monde du travail gradually moved away from the oppositional forms of coverage which had characterised its predecessor. This trajectory was already signalled in September 1933 when the title was formally contracted to Regards. Such a title is close enough to $V u$ and the magazine increasingly came to resemble that type of publication; its coverage was uncoupled from the programmatic to become in its own way heterogeneous. And as the magazine came increasingly to resemble examples of the bourgeois press, its calls for collaborators became less frequent. It was thus ever more difficult to perceive the readers of Regards as its writers.

Yet that the press could hold out the possibility of readers becoming writers was an idea Benjamin was to return to again and again over the course of the $1930 \mathrm{~s}$. He first sketched his own view of the transformation of journalism in 1931, arguing that 'the complete takeover of literature by the newspaper' is a 'prognosis of things to come' ${ }^{87}$ It is

in fact a dialectical process. [...] For as writing gains in breadth what art loses in depth, the separation between the author and the public - a separation that journalism maintains in a corrupt way - starts to be overcome in an admirable way. The reader is ready at any moment to become a writer - that is to say, a describer and prescriber. ${ }^{88}$ 
Lenin is echoed here, albeit faintly. ${ }^{89}$ Benjamin returned to this argument in a very brief essay on the newspaper published in March 1934. ${ }^{90}$ He then cited that essay almost in its entirety in a lecture given the following month: 'The Author as Producer'. ${ }^{91}$ Here he attributed his own words to an anonymous 'left-wing author' and no doubt some pleasure was derived from the perversity of making himself as a writer into a reader. ${ }^{92} \mathrm{He}$ delivered the lecture in Paris less than three months after the first tentative reconciliation of the French Communists and Socialists; nevertheless, he already felt it necessary to qualify his argument. He sees the possibility of a revival of writing but locates that revival 'in the press of Soviet Russia' ${ }^{93}$ Benjamin now seems to doubt that it could take place elsewhere.

These doubts become more evident in the subsequent revisions Benjamin made to this argument in his famous essay on the artwork and reproduction. Here he restricts himself to noting that the 'distinction between author and public is about to lose its axiomatic character' ${ }^{94}$ He does not see this as a prognosis of things to come. Instead of transformation he sees impediments, and places emphasis on 'capitalist exploitation' with its characteristic distortions and corruptions.

Why, then, was Benjamin so attached to the idea of transformation? I think that what he saw here was the possibility of challenging at least certain forms of alienation. This returns me to the question of the status of work. For work is distinct from alienated labour where the latter is understood as the creation of exchange-value, which is only measured quantitatively. The worker, as the possessor only of labour-power, is alienated from his or her own labour, as it is appropriated by the capitalist. Capital 'sucks up the worker's value-creating power' ${ }^{95}$ One might say that under the exploitative logic of the 
bourgeois press, the technology of photography is similarly alienated. It labours for the press, and those using the technology are also alienated. The alternative was to reimagine the work of photography as work and not as mere labour. The bourgeois press was produced to cater to passive consumers. The alternative was to overcome this distinction and to transform readers into writers, and viewers into photographers.

For a moment these transformations seemed possible and seemed about to be realised. But as Benjamin came to understand this possibility of transformation as restricted to the Soviet Union, it would come to seem an increasingly desperate hope. The official adoption of the doctrine of Socialist Realism in 1934 would be among the lesser repressions enacted by Stalin but signalled clearly enough how the tasks of Socialist construction were to be envisaged. Reluctantly, Benjamin would concede that the Soviet moment had passed.

\section{Epilogue}

The essay by Fels with which I began happened to be published in April 1936. This was the month of the first round of French elections; the second round in May would confirm the victory of leftwing unity and result in the formation of a Popular Front government. The government, of course, was to be one of Republican defence and precisely not one to presage a Republic of soviets. The editors of Regards adapted readily enough to the emergence of the Popular Front, and took to pursuing more conventional policies, including in the uses of photography. One element of this new usage was the dedication of full pages to single photographs. Some of these images were of poverty but then others 
might show, for example, picturesque corners of Paris or circus animals performing; each image was described as a 'photograph to keep'. ${ }^{96}$

The issue of Regards for 9 April 1936 carried an image of a female nude. ${ }^{97}$ Clipped from the magazine, the photographs could serve different functions in different contexts, as decoration or as part of a personal collection. They could operate within conventional registers of the exotic or the picturesque, as the case might be. This was, then, a reversal of the policy of Nos Regards. Photographs here are to be unanchored; they will preserve their status even if the magazine is discarded. They do not take their place in a coherent programme and their principal captions are generic ones which confirm the images as the reader's property. Whatever tasks the editors of Regards now assumed, offering a radical challenge to the bourgeois press was not amongst them.

\section{Captions}

Figure 1. Unknown photographer, untitled, Arts et Métiers Graphiques, 52 (15 April 1936), 31 .

Figure 2. Unknown photographers, 'Où vont nos regards', Nos Regards, 1 (May 1928), n.p.

Figure 3. Unknown photographers, 'Le quartier réservé de Casablanca', Nos Regards, 1 (May 1928), n.p. 
Figure 4. Unknown photographers, 'Très beau mais... trop loin trop cher!', Nos Regards, 4 (August 1928), 4-5.

Figure 5. Unknown photographers, 'Vivent les vacances', Nos Regards, 4 (August 1928), 7.

Figure 6. Unknown photographers, ‘Sports U.S.A. Sports U.S.S.R.' Nos Regards, 10 (February 1929), 12-13.

Figure 7. Unknown worker photographers, 'Photographes ouvriers... collaborez à «Regards»', Regards sur le monde du travail, 3 (March 1932), 11.

Parts of the argument developed here were first presented at the symposium " $\mathrm{La}$ Photographie comme arme": Photographie sociale et documentaire dans les années 30' (INHA, Paris, March 2016). I am grateful to the organisers for the invitation to participate. I am also grateful to the anonymous peer readers for their incisive comments. All translations from the French are those of the author unless otherwise indicated. This essay is for Christian Joschke.

Email for correspondence: s.dell@uea.ac.uk

1 - Florent Fels, 'Comment se fabrique un hebdomadaire', Arts et Métiers Graphiques, 52 (15 April 1936), 34: 'Pour un curieux non prévenu, le spectacle d'un tiroir-classeur, ouvert inopinément, ne serait pas sans provoquer quelque étonnement.' 
2 - 'Où vont nos regards', Nos Regards, 1 (May 1928), n.p: 'Supposons un instant que, par suite d'un cataclysme, notre époque vienne à disparaître brusquement. Deux mille ans plus tard, le hazard ayant permis à un savant de découvrir, comme uniques vestiges de notre «civilisation», un lot de magazines et de journaux illustrés, quelle idée le bonhomme pourrait-il bien se faire de notre $\mathrm{XX}^{\mathrm{e}}$ siècle?'.

3 - Ibid.: 'l'étalage'.

4 - Ibid.: 'le monde du travail', 'qu'ignorent systématiquement', 'infiniment plus important et plus précieux'.

5 - There was an established iconography of the Parisian trades. For a discussion of the photographic versions at the beginning of the twentieth century see Molly Nesbit, Atget's Seven Albums, New Haven, CT: Yale University Press 1992.

6 - The historiography of Soviet photography has been complicated by a number of factors. For a clear and concise overview see Margarita Tupitsyn, 'The Histories of the Soviet Photograph: At Home and Abroad', History of Photography, 24: 4 (Winter 2000), 313-16. It is not perverse to examine Soviet photography through a French case as the Communist project in the interwar period was an international one; accounts of this project which are restricted to the Soviet Union are in important respects incomplete. For an approach to some of these issues in the history of photography which is international in scope see The Worker Photography Movement, 1926-1939: Essays and Documents, ed. Jorge Ribalta, Madrid: Museo Nacional Centre de Arte Reina Sofía 2011. 7 - The central strand of the narrative is formed by Lenin's Collected Works, publication of which began in 1920. For a concise but effective overview of the narrative and its construction see James D. White, Lenin: The Practice and Theory of Revolution, 
Basingstoke: Palgrave 2001, esp. 178-202. The issue of the continuities between Lenin's policies and Stalin's has generated controversy since the 1920s; this is not the place to enter the debate. The account offered here is concerned principally with party organisation and here at least I believe the continuities are clear enough. For an overview of the state of debate see Bolshevism, Stalinism and the Comintern: Perspectives on Stalinization, 1917-53, ed. Norman LaPorte, Kevin Morgan, and Matthew Worley, Basingstoke: Palgrave Macmillan 2008.

8 - V. I. Lenin, 'Draft and Explanation of a Programme for the Social-Democratic Party' (1895-96), in Collected Works, vol. 2, Moscow: Foreign Languages Publishing House 1963, 96.

9 - Ibid., 117.

10 - V. I. Lenin, 'What is to be done?' (1902), in Collected Works, vol. 5, Moscow:

Foreign Languages Publishing House 1961, 412 (emphases in original).

11 - Ibid., 425.

12 - Ibid., 452.

13 - Ibid., 502.

14 - V. I. Lenin, 'Party Organisation and Party Literature' (1905), in Collected Works, vol. 10, Moscow: Foreign Languages Publishing House 1962, 45 (emphasis in original). 15 - Ibid., 46. 16 - Georg Lukács, Lenin: A Study on the Unity of his Thought (1924), trans. Nicholas Jacobs, London: New Left Books 1970, 37. 
17 - 'Invitation to the First Congress of the Communist International', in The Communist International, 1919-1943: Documents, vol. 1, ed. Jane Degras, London: Oxford University Press 1956, 3.

18 - Ibid.

19 - 'Conditions of Admission to the Communist International approved by the Second Comintern Congress', in The Communist International, 1919-1943: Documents, vol. 1, $166-72$.

20 - Ibid., 172.

21 - See Statute 8 of the 'Statutes of the International adopted at the Second Congress', in The Communist International, 1919-1943: Documents, vol. 1, 165. The various tensions within the $\mathrm{CI}$ and the attendant historiography are analysed in Kevin McDermott and Jeremy Agnew, The Comintern: A History of International Communism from Lenin to Stalin, Basingstoke: Macmillan 1996.

22 - 'Theses on Tactics adopted by the Fifth Comintern Congress (Extracts)', in The Communist International, 1919-1943: Documents, vol. 2, ed. Jane Degras, London: Oxford University Press 1956, 153.

23 - Ibid., 154.

24 - Ibid.

25 - These developments may be followed through the documentary sources gathered in Le Parti communiste français pendant l'entre-deux-guerres, ed. Nicole Racine and Louis Bodin, Paris: Presses de la Fondation nationale des sciences politiques 1982, 92-139. 26 - J. V. Stalin, 'The October Revolution and the Tactics of the Russian Communists', in Works, vol. 6, Moscow: Foreign Languages Publishing House 1953, 387. 
27 - Ibid., 418 (emphasis in original).

28 - Ibid.

29 - For this sequence of events see Isaac Deutscher, The Prophet Unarmed: Trotsky:

1921-1929, Oxford: Oxford University Press 1970, 246-385.

30 - Albert Sarraut, 'Discours prononcé à Constantine', in Le Parti communiste français

pendant l'entre-deux-guerres, ed. Nicole Racine and Louis Bodin, Paris: Presses de la Fondation nationale des sciences politiques 1982, 153: 'le communisme, voilà l'ennemi!' 31 - 'Projet de programme de l'Internationale communiste', a special supplement to L'Humanité (18 July 1928) 2: 'Dans le cadre de l'économie mondiale, jadis unique, luttent deux systèmes antagonistes: le système du capitalisme et celui du socialisme. Le lutte de classes qui, jusqu'à présent, se déroulait, le prolétariat ne possédant pas son propre pouvoir d'Etat, se reproduit maintenant sur une échelle énorme, vraiment mondiale, la classe ouvrière mondiale possédant déjà son Etat, la seule patrie du prolétariat international. L'existence de l'Union soviétique, son influence mondiale sur les masses travailleuses et opprimées est par elle-même la manifestation la plus éclantante de la profonde crise du système capitaliste mondial, d'une extension et d'une aggravation de la lutte de classe, que l'histoire n'avait encore jamais vues'.

32 - 'The sixth congress of the Communist International', in The Communist International, 1919-1943: Documents, vol. 2, 446-549.

33 - See 'The Ninth Plenum of the Executive Committee of the Communist International', in The Communist International, 1919-1943: Documents, vol. 2, 423-29. 34 - See Babette Gross, Willi Münzenberg: Eine politische Biographie, Stuttgart: DVA 1967, 165-66; and Lilly Becher, 'Vorwort', in Heinz Willmann, Geschichte der Arbeiter- 
Illustrierten Zeitung: 1921-1938, Berlin: Dietz Verlag 1975, 7-11. Nos Regards was an attempt to internationalise the coverage of an earlier French publication focused on the Soviet Union, La Russie Nouvelle, which ran from May 1924 to October 1925. See Christian Joschke, 'La marché transnational des images politiques: Le Secours ouvrier international dans le contexte des agencies photographiques soviétiques (1924-1933)', Etudes photographiques, 35 (Spring 2017), 3-29. Münzenberg does not feature in Nos Regards in its first incarnation. However, he does appear in the later publication Regards sur le monde du travail. See Onof, 'Le S.O.I. au travail', Regards sur le monde $d u$ travail, 3 (March 1932), 9.

35 - 'Invitation to the First Congress', 4.

36 - For a detailed account of Münzenberg's activities, his relations with the CI, and the dynamics of solidarity see Kasper Braskén, The International Workers' Relief, Communism and Transnational Solidarity: Willi Münzenberg in Weimar Germany, Basingstoke: Palgrave Macmillan 2015.

37 - For an overview of this trajectory of German Communism see Andreas Wirschung, 'The Impact of "Bolshevization" and "Stalinization" on French and German Communism: A Comparative View', in Bolshevism, Stalinism and the Comintern, ed. LaPorte, Morgan, and Worley, 89-104. 38 - For one overview of the relationship between the daily and periodical press at this moment see Simon Dell, The Image of the Popular Front: The Masses and the Media in Interwar France, Basingstoke: Palgrave Macmillan 2007, 29-43.

39 - Diane Richmond, 'Le quartier réservé de Casablanca', Nos Regards, 1 (May 1928), n.p. That Nos Regards depended on agency materials is evident from the occasional 
clarifications the editors were obliged to insert after discovering an agency had misidentified a subject. See for example 'Rectification', Nos Regards, 2 (June 1928) 14. On the difficulty of sourcing photographs for Nos Regards see Joschke, 'La marché transnational des images politiques'.

40 - Richmond, 'Le quartier réservé', n.p.: 'Les jolies jeunes femmes que l'on peut voir ici semblent, en général, avoir été choisies pour leur beauté et pour leur grâce par celui qui a pris ces photographies. Mais, en les regardant de plus près, on remarque sur tous ces visages, sans exception aucune, une expression de profonde tristesse, tristesse qui, chez quelques-unes de ces malheureuses, semble aller jusq'au desespoir'.

41 - See for example the popular versions of the official records for the exhibitions in Marseilles in 1922 and Paris in 1931: Adrien Artaud et al., L'Exposition nationale coloniale de Marseille décrite par ses auteurs, Marseilles: Commissariat Général de l'Exposition 1922; and Commissariat Général de 1'Exposition, Le Livre d'Or de l'exposition colonial international de Paris, Paris: Librairie ancienne Honoré Champion 1931.

42 - For North African examples see the presentation of Algeria and Tunisia in Commissariat Général, Le Livre d'Or, 36-38 and 41-43.

43 - Richmond, 'Le quartier réservé', n.p.: 'installe, officiellement'. 44 - Ibid.: 'Afcha, l'une des jeunes "favorites" de "Messieurs blancs", 45 - See the juxtaposition of Sfax as 'European city' and an inhabitant of Sfax in 'Moorish dress' in Commissariat Général, Le Livre d'Or, 41-43. 46 - 'Alsace: Pays du travail', Nos Regards, 3 (July 1928), 2. 
47 - For examples of the Socialist view of colonialism at this date see the essays gathered in Léon Blum, 'Le Problème du colonialisme', in L'Oeuvre de Léon Blum: 1914-1928, vol. 3, i, Paris: Editions Albin Michel 1972, 480-90.

48 - 'Projet de programme', 2.

49 - Ibid.

50 - 'Très beau mais... trop loin trop cher!', Nos Regards, 4 (August 1928), 5: 'vue', 'éclabousse','les estampes nippones'.

51 - Ibid., 4 : 'en rêve’.

52 - 'Vivent les vacances', Nos Regards, 4 (August 1928), 7 : 'un régime qui gaspille le meilleur de ses finances dans les budgets de mort'.

53 - Walter Benjamin, 'The Work of Art in the Age of Its Technological

Reproducibility', in Selected Writings, vol. 4, ed. Howard Eiland and Michael W.

Jennings, trans. Edmund Jephcott and Others, Cambridge, MA: The Belknap Press of Harvard University Press 2003, 258.

54 - Ibid.

55 - The first issue of $V u$ appeared on 21 March 1928.

56 - See 'L'auto dans l'oeil du phare', Vu, 29 (3 October 1928), 647 ; and 'En luttant

contre... le brouillard et la nuit', $V u, 185$ (30 September 1931), 2284-2285.

57 - This image of the magazine is presented in 'Remarques sur un nouveau journal illustré', $V u, 1$ (21 March 1928), 11-12. For a discussion of the editorial policies of $V u$ see Michel Frizot and Cédric de Veigy, Vu: The Story of a Magazine that Made an Era, trans. Ruth Sharman, London: Thames \& Hudson 2009.

58 - Lenin, 'Party Organisation', 45. 
59 - Ibid.

60 - 'Qui veut la guerre, prépare la guerre', Nos Regards, 4 (August 1928), 8-9.

61 - Géo Charles, 'Olympiades Spartakiades', Nos Regards, 4 (August 1928), 12.

62 - Ibid.: 'une fausse neutralité'.

63 - Ibid.: 'une espèce de monstre'.

64 - As noted above the first editorial in Nos Regards is unsigned and the first issues carry no indication of an editor or an editorial board. However, Dutilleul was well qualified for the job of director, being active in the sections of the PCF dedicated to propaganda and also having close links with Münzenberg's Internationale Arbeiterhilfe. See 'Dutilleul, Emile', in Dictionnaire biographique du movement ouvrier français, vol. 26, ed. Jean Maitron, Paris: Les Editions Ouvrières 1964-98, 298-300. 65 - ‘Sports U.S.A. Sports U.R.S.S.', Nos Regards, 10 (February 1929), 12-13. 66 - Lenin, ‘Party Organisation', 46.

67 - Philippe Robrieux, Histoire intérieure du Parti communiste, vol. 1, Paris: Fayard 1980, 339-41. On the role of Tardieu in the folding of Nos Regards, see E. Dutilleul, 'Un A.I.Z. en France?', Regards, 11 (November 1932), 2.

68 - Bernard Pudal, Prendre parti: pour une sociologie historique du PCF, Paris: Presses de la Fondation nationale des sciences politiques 1989. 69 - This was set out in a series of articles in L'Humanité in July and August 1931: see Robrieux, Histoire intérieure, 358-60. 70 - Continuities between the publications are emphasised in Dutilleul, 'Un A.I.Z. en France?'. 
71 - 'A nos lecteurs', Regards sur le monde du travail, 2 (February 1932) 11: ‘des faits sociaux et politiques les plus saillants, les actualités satiriques, les contrastes les plus frappants que nous donnent la crise mondiale, par ses spectacles de misère inouïe'. 72 - Ibid.: 'l'autre monde du travail, celui qui tient librement ses destinées en mains, l'U.R.S.S'

73 - L. Dieulle, 'Logements ouvriers'; and 'En U.R.S.S.', Regards sur le monde du travail, 2 (February 1932), 4-5, and 6.

74 - 'A nos lecteurs': ‘《REGARDS» peut et doit devenir un organe illustré de collaboration des masses. Il sera ce que les lecteurs voudront qu'il soit, parce qu'il sera toujours tenu largement compte des critiques, suggestions, observations et propositions qui parviendront au Comité de Rédaction.

Plus le nombre de collaborateurs, photographes et rédacteurs sera grand, plus nous aurons le choix des sujets à présenter, plus notre revue sera variée et attrayante, parce qu'elle sera l'émanation de la masse des lecteurs'. 75 - 'Le Manifeste de l'Association des Ecrivains et Artistes révolutionnaires', L'Humanité (22 March 1932), 4: 'La lutte des classes revêt à l'échelle universelle l'aspect de deux systèmes en concurrence, l'impérialisme pourrissant et le jeune socialisme. [...] C'est que, pour la première fois depuis la Commune de Paris, les prolétaires, par-dessus toutes les frontières, ont un Etat à eux. Les travailleurs ont une patrie et dans cete $[s i c]$ patrie se lève, avec le second Plan quinquennial, l'aube de la société sans classes.

Une nouvelle civilisation commence'. 
76 - Ibid. : 'L'époque de l'impérialisme est l'époque du dépérissement et de la dislocation de la culture bourgeoise. [...] Ici encore les deux mondes s'opposent clairement. C'est au prolétariat que revientla charge de relever la culture mondiale'. 77 - For an analysis of the Association des Ecrivains et Artistes révolutionnaires, see Wolfgang Klein, Commune: Revue pour la défense de la culture (1933-1939), trans. D. Bonnaud-Lamotte with M.-A. Coadou, Paris: Editions du Centre national de la recherche scientifique 1988; and for the broader project of cultural renewal see Pascal Ory, La Belle Illusion: Culture et Politique sous le signe du Front populaire, 1934-1938, Paris: Plon 1994.

78 - 'Le Manifeste', 4: 'la littérature ne peut devenir une source d'enrichissement pour des personnes ou des groupement, ni une affaire individuelle, indépendante de la cause générale du prolétariat'.

79 - 'Le Manifeste de l'Association des Ecrivains et Artistes révolutionnaires', L'Humanité (29 March 1932), 4: 'le réservoir', 'des cadres sans cesse renouvelés d'écrivains prolétariens'.

80 - Ibid.: '[d]évelopper l'art de masse dans ses forms Nouvelles d'expression, théâtreouvrier $[\ldots]$ photo-montage, cinema, radio, etc.'

81 - The issue of L'Humanité which carried the first instalment of the manifesto also carried an article on the rabcors. See Pierre RABCOR, 'En février 316 lettres et 3 pages de rabcors ont paru dans “L'Huma”", L'Humanité (22 March 1932), 6. 82 - 'Photographes ouvriers...', Regards sur le monde du travail, 3 (March 1932), 11: 'avec le style bourgeois dont nous sommes malheureusement encore imprégnés'. 
83 - Ibid.: 'jugez de la pose d'une vedette, d'une «étoile», dont s'enorgueillissent toutes les revues illustrées éditées à des millions d'exemplaires. C'est une distraction, diront certains, que de feuilleter de tells revues. La bourgeoisie, elle sait que c'est un moyen d'égarer les travailleurs et puis de faire de «bonnes affaires»

Les lecteurs de «REGARDS» sont sortis de ce bourbier. Ils n'abandonnent pas leur classe'. Worker photography was first developed in Germany in 1926. A French association of worker photographers was founded in 1930. See Ribalta, The Worker Photography Movement.

84 - Lenin, 'Party Organisation', 46. It should be noted that the transformation of worker into photographer was to be mirrored by the redefinition of photographers as workers. See 'COMMUNE présente un projet de revendications des travailleurs intellectuels', Commune (July 1933), 87-95.

85 - See for example 'Extracts from the theses of the twelfth ECCI plenum on the international situation and the tasks of the Comintern sections', in The Communist International, 1919-1943: Documents, vol. 3, ed. Jane Degras, London: Oxford University Press 1965, 210-44.

86 - This summary compresses much. For a full account of the crisis of February see Serge Berstein, Le 6 février 1934, Paris: Gallimard 1975. For the response of the PCF see Denis Peschanski, Et pourtant ils tournent: Vocabulaire et strategie du PCF, 19341936, Paris: Klincksieck 1988.

87 - Walter Benjamin, 'Diary from August 7, 1931, to the Day of My Death', in Selected Writings, vol. 2, ed. Howard Eiland, Michael W. Jennings, and Gary Smith, trans. 
Rodney Livingstone and Others, Cambridge, MA: The Belknap Press of Harvard University Press 1999, 504.

88 - Ibid., 504-05.

89 - Benjamin may also have had in mind the account of journalism as 'the apogee of capitalist reification' in Georg Lukács, History and Class Consciousness: Studies in Marxist Dialectics (1923), trans. Rodney Livingstone, London: Merlin Press 1971, 100. 90 - Walter Benjamin, 'The Newspaper', in Selected Writings, vol. 2, 741-42.

91 - Walter Benjamin, 'The Author as Producer', in Selected Writings, vol. 2, 771-72. 92 - Ibid., 771.

93 - Ibid.

94 - Benjamin, ‘The Work of Art', 262.

95 - Karl Marx, Capital (1867), vol. 1, trans. Ben Fowkes, London: Penguin Books $1990,716$.

96 - For example, Regards, 113 (12 March 1936), 12; Regards, 116 (2 April 1936), 11. 97 -Regards, 117 (9 April 1936), 11: 'Une photo à conserver'. 